\title{
HIV and Menopause: A Systematic Review of the Effects of HIV Infection on Age at Menopause and the Effects of Menopause on Response to Antiretroviral Therapy
}

\author{
Kentaro Imai, ${ }^{1}$ Madeline Y. Sutton, ${ }^{2}$ Rennatus Mdodo, ${ }^{2,3}$ and Carlos del Rio ${ }^{4}$ \\ ${ }^{1}$ Rollins School of Public Health, Emory University, Atlanta, GA 30333, USA \\ ${ }^{2}$ Division of HIV/AIDS Prevention, Centers for Disease Control and Prevention, Atlanta, GA 30333, USA \\ ${ }^{3}$ Epidemic Intelligence Service, Centers for Disease Control and Prevention, Atlanta, GA 30333, USA \\ ${ }^{4}$ Hubert Department of Global Health, Emory University, Atlanta, GA 30333, USA
}

Correspondence should be addressed to Madeline Y. Sutton; msutton@cdc.gov

Received 24 July 2013; Revised 8 October 2013; Accepted 22 October 2013

Academic Editor: W. T. Creasman

Copyright (C) 2013 Kentaro Imai et al. This is an open access article distributed under the Creative Commons Attribution License, which permits unrestricted use, distribution, and reproduction in any medium, provided the original work is properly cited.

\begin{abstract}
More than half of persons living with HIV infection in the United States (U.S.) will be $\geq 50$ years of age by 2020 , including postmenopausal women. We conducted a systematic literature review about the effects of (1) HIV infection on age at menopause and (2) menopause on antiretroviral therapy (ART) response, in order to inform optimal treatment strategies for menopausal women living with HIV infection. We used the Ovid Medline database from 1980 to 2012. We included studies that focused on HIV-infected persons, included postmenopausal women, and reported outcome data for either age at menopause or response to ART across menopause. We identified six original research articles for age at menopause and five for response to ART across menopause. Our review revealed that current data were conflicting and inconclusive; more rigorous studies are needed. Disentangling the effects of menopause requires well-designed studies with adequate numbers of HIV-infected and HIV-uninfected women, especially disproportionately affected women of color. Future studies should follow women from premenopause through menopause, use both surveys and laboratory measurements for menopause diagnoses, and control for confounders related to normal aging processes, in order to inform optimal clinical management for menopausal women living with HIV.
\end{abstract}

\section{Introduction}

Globally, persons with human immunodeficiency virus (HIV) are living longer, healthier lives, due largely to the widespread use of effective highly active antiretroviral therapy (HAART) [1, 2]. It is projected that by 2015-2020, half of persons living with HIV infection in the United States will be 50 years of age or older [3,4] and likely living with and managing other comorbid, chronic medical conditions that often accompany the aging process. These conditions include hypertension, diabetes, and for women, who make up half of all persons living with HIV infection worldwide, menopause [5]. For HIV-infected women taking effective ART, this longer survival translates into many women likely living beyond menopause well into their postmenopausal years. Yet large gaps exist in our understanding of the effect of HIV on the aging process for HIV-infected women as they approach and live through menopause. Prioritizing efforts to learn more about the potential impact of HIV on the lives of menopausal women are warranted in an effort to optimize care and treatment for older HIV-infected women.

In 2011, an estimated $25 \%$ of U.S. adults and adolescents living with HIV infection were women; many were near or already into their menopausal years (Figure 1) [6]. Substantial racial/ethnic disparities have been noted among women living with HIV infection across all age groups; among women living with and newly diagnosed with HIV infection in 2011, black/African Americans and Hispanics/Latinas were disproportionately represented (Figure 2) [6-9]. Understanding the effects of HIV on women and menopause could contribute to efforts to understand and close HIV-related racial/ethnic disparities. 


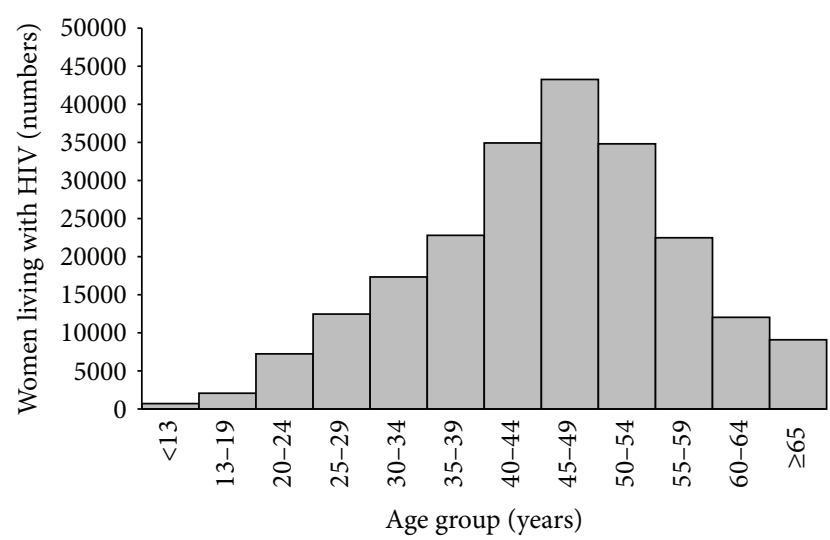

FIGURE 1: Estimated numbers of women living with HIV infection, 46 states, United States, 2011. Estimates were calculated based on data provided in [6].

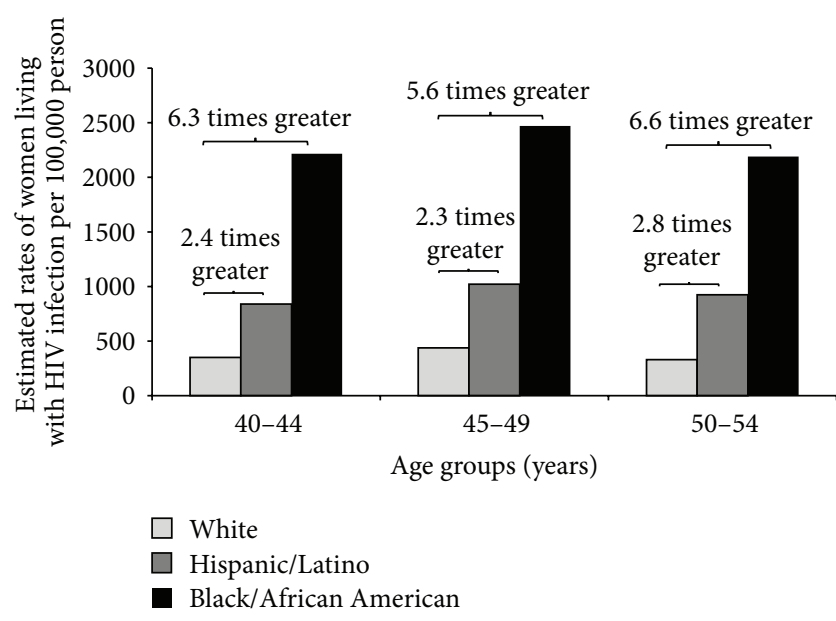

FIGURE 2: Estimated rates of women living with HIV infection, by age groups, $40-44,45-49$, and 50-54 years, among all women, by race/ethnicity in 46 states, United States, 2011. Estimates were calculated based on data provided in [6].

To date, there have been inconsistent reports regarding several areas related to HIV-infected women and menopause. HIV-infected women were reported to lose ovarian function earlier in life than HIV-uninfected women, leading to an earlier onset of menopause among HIV-infected women [10]. Over the short term, a menopausal transition is associated with an altered mood state and sexual dysfunction, both of which can affect quality of life for women $[11,12]$. Over the long term, menopause accelerates the onset and progression of chronic diseases of aging, including cardiovascular disease, hypertension, diabetes, and reduced bone mineral density $[13,14]$. All of these risks suggest a possible increased burden of disease for HIV-infected women if they enter menopause at an earlier age and are living longer lives on effective ART treatment [15]. Our objectives were to conduct a systematic review of the literature to summarize data regarding: (1) age of menopause among women living with HIV infection, and (2) immunological and virological response to ART in
HIV-infected menopausal women. Our goal was to identify research gaps, including questions regarding racial/ethnic disparities, and inform future initiatives to ensure optimal medical management for older HIV-infected women.

\section{Methods}

We conducted a literature search using the Ovid Medline database from 1980 to August 2012 to identify relevant articles. The search was limited to articles published in English that described studies of menopausal transition among HIVinfected humans. We focused on two topics: (1) age at menopause and (2) immunological and virological response to ART across menopause. We felt that understanding the age at which HIV-infected women went through menopause would provide important, informative context about their responses to ART, especially related to possible menopause-related symptoms/side effects; this information may be helpful to clinical providers who care for HIV-infected, older women. Search strategies used the keywords "HIV" and "menopause." Additional search terms - added to yield the highest number of possible articles-included (1) for age at menopause, "age," "aging," "age at menopause," "age of menopause," "early," and "early menopause" and (2) for response to ART across menopause, "antiretroviral" (ARV), "HAART," "ART," "ARV," "treatment," "response," "response to ART," "CD4," and "viral load." Final original research articles included (1) original research articles that studied age at menopause in HIVinfected women, and (2) original research articles that examined the difference in response to ART across menopause in HIV-infected women.

We also reviewed research articles using the same search terms as above that compared ART responses among HIVinfected men and women aged $\leq 40$ years with age $\geq 55$ years to supplement our review of ART response across menopause among HIV-infected women. Some studies documented a wide median age range (39-53 years) for menopause among women living with HIV [16-18]. Most women have either entered or completed their menopausal transition by the age of 50 and almost all by the age of 55 [19]. HIV-infected women aged $\leq 40$ years or aged $\geq 55$ years may be characterized as premenopausal or postmenopausal, respectively, but documentation of menopausal status may vary depending on available clinical laboratory details reported in studies. Also, some studies have shown that immunological and virological response to ART do not differ by gender after adjusting for other factors, including age, race/ethnicity, and ART regimen [20-24].

\section{Results}

3.1. Final Articles Included in Review. The process for article selection and exclusion is summarized in Figure 1. For age at menopause, 63 articles were identified, of which four were original research articles $[16,18,25,26]$ and 11 were review articles $[10,15,17,27-34]$. Forty-eight of 63 were excluded, because age at menopause in HIV-infected women was not discussed. In the 11 review articles, two more original research 


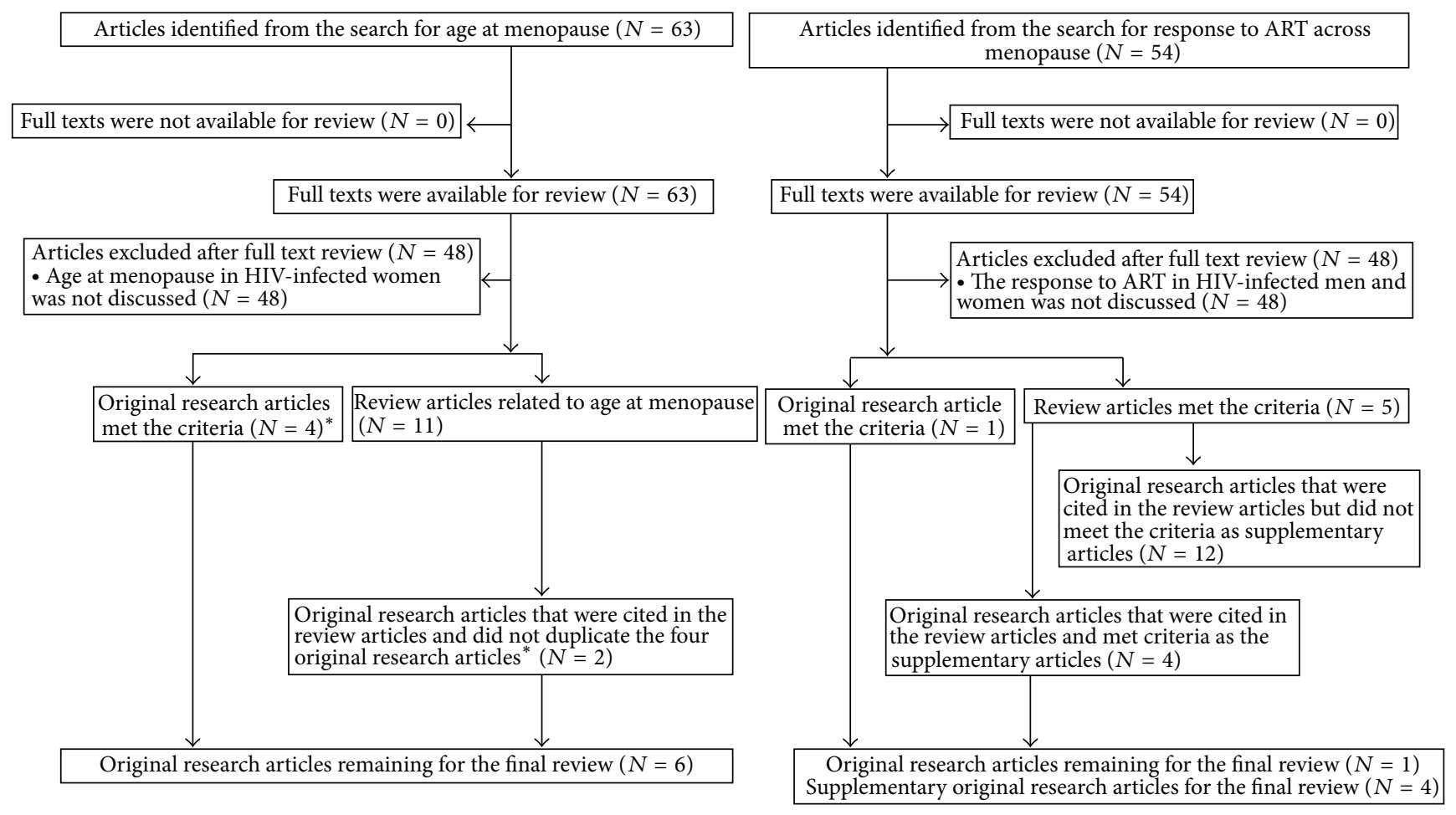

FIGURE 3: Flowchart of article selection and exclusion for the systematic review: HIV and menopause, 1980-2012.

articles $[17,35]$ that did not duplicate the four original research articles $[16,18,25,26]$ were identified, for a total of six original research articles $[16-18,25,26,35]$ for the review of age at menopause in HIV-infected women (Figure 3).

For ART response among HIV-infected persons, 54 articles were identified. Of those, a single original research article [36] and five review articles [4, 28, 34, 37, 38] that reported response to ART in HIV-infected women were identified; 48 of 54 were excluded, because immunological response to ART in HIV-infected patients was not discussed. In the five review articles, 16 original research articles regarding response to ART in HIV-infected patients [24, 39-53] were also reviewed as possible supplementary articles. Of these, four original research articles [39-42] that contained useful information about the two age groups of HIV-infected men and women (ages $\leq 40$ years and $\geq 55$ years) were selected as supplementary articles for the final review. Overall, one article that enrolled HIV-infected women only and four supplementary original research articles (five total) [36, 39-42] were selected for the final review of response to ART among HIV-infected persons across menopause (Figure 1).

3.2. Age at Menopause. Age at menopause of HIV-infected women was reported in six studies [16-18, 25, 26, 35] (Table 1). Four studies were conducted in the United States with racially and ethnically diverse groups of participants (consistent with the United States' epidemiology of HIV among women) [16, 17, 26, 35], one in Brazil [25] and one in France [18]. In four of the six studies, the authors assessed median age at menopause in describing age at menopause [16-18, 25]; the remaining two studies assessed mean age at menopause $[26,35]$. All six studies [16-18, 25, 26, 35] defined menopause as amenorrhea for 12 consecutive months [54].

Three of the six studies found no difference in age at menopause among HIV-infected [17, 18, 35] and HIVuninfected women [36]. Cejtin et al. found no significant difference in the mean age at menopause between HIV-infected and HIV-uninfected women in the Women Interagency HIV Study (WIHS): 47.7 and 48.0 years, respectively [35]. The WIHS study participants were demographically similar to those in a study by Fantry et al. [17], in terms of race/ethnicity, level of education, socioeconomic status, and drug use, all of which have been reported to influence age at menopause [55]. The median age at menopause for HIV-infected women was 50 years (IQR: 49-53) in the Fantry et al. study [17] and 49 years (IQR: 40-50) in a study by de Pommerol et al. [18], similar to what has been reported with large multiethnic population-based samples of HIV-uninfected women (median age for menopause $=50-52$ years) in the United States $[56,57]$ and Europe [58, 59].

In contrast, the other three studies $[16,25,26]$ reported that menopause started at a younger age in HIV-infected women (Table 1). A single cohort study by Schoembaum et al. reported a significant lower median age at menopause in HIV-infected women (46.0 years, IQR: 39.0-49.0), compared with HIV-uninfected women (47.0 years, IQR: 44.5-48.0, $P=$ 0.03 ) [16]. In an analysis using multivariate logistic regression with adjustment for age, these authors demonstrated that $\mathrm{HIV}$-infected women were $73 \%$ more likely to experience premature menopause compared with HIV-uninfected women (OR: 1.73, 95\% confidence interval [CI]: 1.08-2.80, $P=0.024$ ) [16]. Two other studies from Ferreira et al. and Clark et al. that 
TABLE 1: Studies available through 2012 evaluating age at menopause in HIV-infected women.

\begin{tabular}{|c|c|c|c|c|c|c|c|c|}
\hline $\begin{array}{l}\text { Authors } \\
\text { (year) }\end{array}$ & Country & $\begin{array}{l}\text { Number of } \\
\text { women for } \\
\text { analysis }\end{array}$ & $\begin{array}{c}\text { Percent of participants } \\
\text { who were black/African } \\
\text { American or } \\
\text { Hispanic/Latina }\end{array}$ & HIV status & $N$ & $\begin{array}{l}\text { Number of } \\
\text { women with } \\
\text { menopause }\end{array}$ & $\begin{array}{l}\text { Age at onset of } \\
\text { menopause (years) }\end{array}$ & $P$ value \\
\hline $\begin{array}{l}\text { Clark et al. } \\
(2000)[26]\end{array}$ & United States & 52 & $\begin{array}{l}\text { 43\% (black/AA) } \\
15 \% \text { (Hispanic) }\end{array}$ & $\begin{array}{c}\text { Infected } \\
\text { Uninfected }\end{array}$ & $\begin{array}{c}52 \\
0\end{array}$ & $\begin{array}{l}26(50.0 \%) \\
\text { NA }\end{array}$ & $\begin{array}{c}47 \text { (IQR 32-57) (mean) } \\
\text { NA }\end{array}$ & NA \\
\hline $\begin{array}{l}\text { Cejtin et al. } \\
(2004)[35]\end{array}$ & United States & 1335 & NR & $\begin{array}{l}\text { Infected } \\
\text { Uninfected }\end{array}$ & $\begin{array}{c}1063 \\
272\end{array}$ & $\begin{array}{l}\text { NR } \\
\text { NR }\end{array}$ & $\begin{array}{l}47.7 \text { (mean) } \\
\quad 48.0\end{array}$ & NS \\
\hline $\begin{array}{l}\text { Fantry et al. } \\
(2005)[17]\end{array}$ & United States & 120 & 95\% (black/AA) & $\begin{array}{l}\text { Infected } \\
\text { Uninfected }\end{array}$ & $\begin{array}{c}120 \\
0\end{array}$ & $\begin{array}{l}\text { NR } \\
\text { NA }\end{array}$ & $\begin{array}{c}50.0(\text { IQR } 49.3-53.0) \\
\text { (median) } \\
\text { NA }\end{array}$ & NA \\
\hline $\begin{array}{l}\text { Schoenbaum } \\
\text { et al. }(2005) \\
{[16]}\end{array}$ & United States & 571 & $\begin{array}{l}49 \% \text { (black/AA) } \\
40 \% \text { (Hispanic) }\end{array}$ & $\begin{array}{l}\text { Infected } \\
\text { Uninfected }\end{array}$ & $\begin{array}{l}302 \\
269\end{array}$ & $\begin{array}{l}62(20.5 \%) \\
40(14.9 \%)\end{array}$ & $\begin{array}{l}46.0(\text { IQR } 39.0-49.0) \\
47.0 \text { (IQR 44.5-48.0) }\end{array}$ & 0.03 \\
\hline $\begin{array}{l}\text { Ferreira et al. } \\
(2007) \text { [25] }\end{array}$ & Brazil & 251 & NA & $\begin{array}{l}\text { Infected } \\
\text { Uninfected }\end{array}$ & $\begin{array}{r}96 \\
155\end{array}$ & $\begin{array}{l}\mathrm{NR} \\
\mathrm{NR}\end{array}$ & $\begin{array}{l}47.5 \text { (median) } \\
\text { NR }\end{array}$ & NR \\
\hline $\begin{array}{l}\text { de Pommerol } \\
\text { et al. (2011) [18] }\end{array}$ & France & 404 & NA & $\begin{array}{l}\text { Infected } \\
\text { Uninfected }\end{array}$ & $\begin{array}{c}404 \\
0\end{array}$ & $\begin{array}{l}69(17.1 \%) \\
\text { NA }\end{array}$ & $\begin{array}{c}49 \text { (IQR 40-50) (median) } \\
\text { NA }\end{array}$ & NA \\
\hline
\end{tabular}

AA: African American, IQR: interquartile range, NA: not applicable, NR: not reported, NS: not significant.

included only HIV-infected women reported median ages at menopause of 47.5 years (IQR not provided) [25] and 47 years (IQR: 32.0-57.0), respectively [26].

In one study included in this review, de Pommerol et al. examined premature menopause (onset before age 40 years) and reported that $12 \%$ of postmenopausal HIV-infected women sampled had experienced premature menopause [18]. This prevalence of premature menopause among HIVinfected women was higher than the reported prevalence of $1.1-6.3 \%$ among women in the general population of HIVuninfected women enrolled in the American Study of Women's Health Across the Nation cohort, although the sampled populations were different demographically [60, 61]. Other reports have noted comparable mean ages at menopause between HIV-infected and HIV-uninfected women but found a disproportionate number of HIV-infected women with a younger median age for menopause $[62,63]$.

Three studies examined the association of CD4 cell count with age at menopause [18-20]. Schoembaum et al. reported that a CD 4 cell counts of $>500$ cells $/ \mathrm{mm}^{3}$ (OR: $0.19,95 \% \mathrm{CI}$ : $0.08-0.48, P=0.001$ ) and $200-500$ cells $/ \mathrm{mm}^{3}$ (OR: $0.35,95 \%$ CI: $0.15-0.81, P=0.015)$ was independently associated with a decreased risk of premature menopause compared with a CD 4 cell count $<200$ cells $/ \mathrm{mm}^{3}$ [16]. The median age of menopause was 42.5 years in HIV-infected women with CD 4 cell counts of $<200$ cells $/ \mathrm{mm}^{3}$, while the median age of menopause was 46.0 years in those with CD4 cell counts of 200500 cells $/ \mathrm{mm}^{3}$ and 46.5 years in those with CD 4 cell counts of $>500$ cells $/ \mathrm{mm}^{3}(P=0.009)$ [16]. de Pommerol et al. reported that a CD 4 cell count of $<200$ cells $/ \mathrm{mm}^{3}$ at enrollment was also associated with an earlier onset of menopause, compared with a CD4 cell count of $>350$ cells $/ \mathrm{mm}^{3}$ (HR: $2.25,95 \%$ CI: 0.94-5.39, $P=0.069$ ) [18]. Fantry et al. also showed no significant association between lower CD4 cell count and onset of menopause [17].

Although the same definition was used for menopause for all six studies, each used different methods for documenting age at menopause, and all evaluated menopause at a single time point [16-18, 25, 26, 35]. Evaluating the presence of menopause at only one time point could have led to an overestimation of its prevalence. Only the Cejtin et al. study [35] measured menopause using laboratory biologic markers, including follicle stimulating hormone (for diagnosing menopause, in addition to self-reported menopausal status, multiple consistently elevated serum FSH levels are useful as a laboratory marker [17] and can help distinguish menopause from other causes of amenorrhea [54, 64].) in addition to the women's self-report of amenorrhea (FSH). The other five studies [16-18, 25, 26] used only self-reported questionnaire data to document age at menopause and did not confirm menopause biologically. Thus, age at menopause reported in the five studies $[16-18,25,26]$ could be different from the age when the women actually experienced menopause, as no laboratory verifications were obtained and misdiagnoses of menopause in $\mathrm{HIV}$-infected women were possible.

\subsection{Immunological and Virological Response to ART across} Menopause. To evaluate response to ART in HIV-infected women and men, we reviewed studies that examined changes in CD4 cell counts (immunological response) and plasma HIV RNA viral loads (virological response) after initiation of ART [21, 36, 39, 40, 44, 49-51]. We identified only one study that examined response to ART in HIV-infected women with well-characterized menopause [36]. This study (Table 2) included $267 \mathrm{HIV}$-infected racially and ethnically diverse women (220 premenopausal and 47 postmenopausal) and 


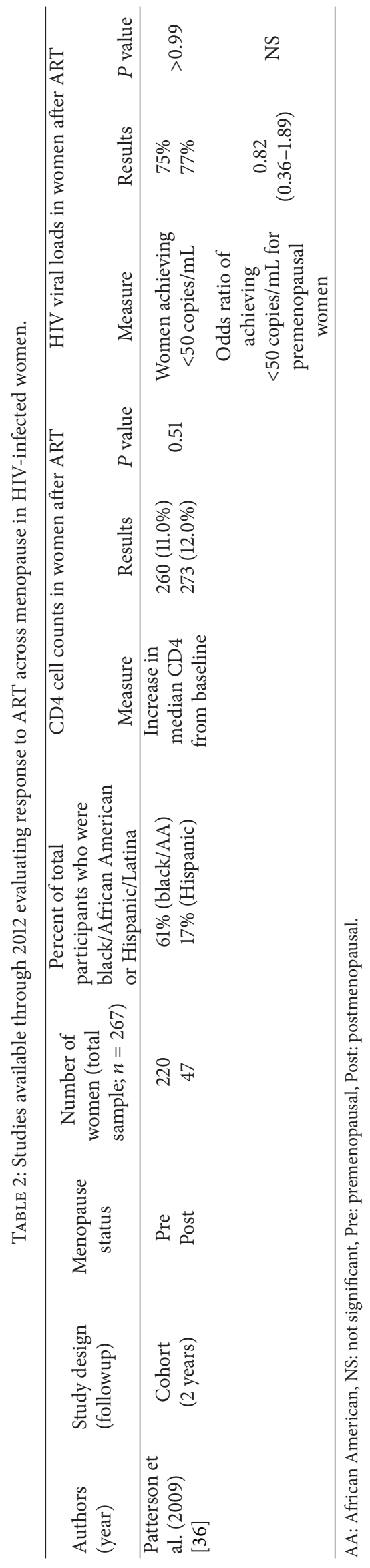


demonstrated that the median change in absolute CD4 cell counts and percentages did not differ between premenopausal and post-menopausal women after two years of ART (260 versus 273 cells $/ \mathrm{mm}^{3}, P=0.51 ; 11.0 \%$ versus $12.0 \%$, $P=0.79$ ) [36]. There were also no differences between premenopausal and post-menopausal women in the proportions achieving plasma HIV RNA viral loads $<50$ copies/mL after two years of HAART (75\% versus $77 \%, P>0.99$; OR: 0.82 , 95\% CI: 0.36-1.89) [36]. These data suggest that both pre- and post-menopausal HIV-infected women compared with uninfected women respond equally well to ART during at least the first two years after initiation.

We also identified four supplementary original research articles regarding ART response among both men and women living with HIV infection (Table 3) [39-42]. Two studies [41, 42] included only ART-naïve HIV-infected men and women in the pre-menopausal and post-menopausal age ranges, whereas the two other studies $[39,40]$ included some ART-experienced patients. Three of the four supplementary articles analyzed data from European cohorts [39-41]. The fourth used data from the United States and Canada (North American AIDS Cohort Collaboration on Research and Design) and consisted of $83 \%$ male patients [42].

Regarding immunological response to ART, Manfredi and Chiodo found that both men and women aged $\geq 55$ years who started ART had a significantly smaller increase in mean CD4 cell counts compared with persons aged $\leq 35$ years (77 versus 114 cells $/ \mathrm{mm}^{3}, P=0.0001$ ) [39]. However, Knobel et al. and Althoff et al. concluded that there was no significant difference in immunological response between HIV-infected men or women comparing persons age $\leq 40$ years with persons age $\geq 60$ years $[40,42]$. Finally, the Collaboration of Observational HIV Epidemiological Research in Europe (COHERE) study showed that HIV-infected men and women combined aged 55-59 years had a similar immunological response to ART compared with persons aged 30-39 years (HR: 0.97, 95\% CI: 0.92-1.03, P=0.31) [41]. However, HIVinfected women aged $\geq 60$ years in the COHERE study were $7 \%$ less likely to experience immunological response compared with women aged 30-39 years (HR: 0.93, 95\% CI: 0.87$0.98, P<0.001)$ [41].

Regarding virological response to ART, both the Manfredi et al. and Knobel et al. studies reported that HIVinfected men and women aged $\leq 35$ years [39] or aged $\leq 40$ years [40] had no significant difference in either the decrease in mean plasma HIV RNA viral load or the number of patients achieving $<50$ copies/mL, compared with those aged $\geq 55$ or aged $\geq 60$, respectively (Table 3 ) $[39,40]$; these studies were limited by small sample sizes. However, the COHERE study (>49,900 participants) showed that the probability of virological response was $24 \%$ higher in patients aged 55-59 years than those aged 30-39 years (HR: 1.24, 95\% CI: 1.17-1.32, $P<0.001)$ [41]. In contrast, Althoff $(>12,000$ participants) showed that the hazard of achieving $<500$ copies/mL of HIV viral loads within two years after ART initiation in HIVinfected patients aged $\geq 60$ years was $26 \%$ less than that in patients aged 18-29 years [42].
Overall, the outcomes of the four supplemental studies [39-42] were conflicting. Possible reasons include having used different age categories for comparison, variation in study sample size, and lack of data for women only. Moreover, none of the four studies, which sampled both men and women with HIV infection, stratified data by sex, and menopause status to permit comparison with the Patterson et al. study [36], which consisted solely of women. The number of men was significantly greater than that of women for studies in Table 3 and could have affected study outcomes. Some studies, not included in our review because data on menopause were not reported, suggest that immunological and/or virological responses to ART differ by gender and among all age groups after adjusting for other factors [22, 65, 66].

\section{Discussion}

Our review revealed that current data on age at menopause and the effect of menopause on the response to ART for HIVinfected women are conflicting. Part of the challenge is that existing studies have not adequately distinguished the unique contribution, if any, of HIV infection or its consequences such as lower CD4 cell count $[16,18]$, from the contribution of other risk factors for early menopause irregular menses [15], such as drug use [18], tobacco smoking [67], black/African American race [18], fewer years of education [16, 57], and lower body mass index (BMI) $[54,59]$, all of which are common among persons living with HIV infection. Many current reports have been limited to cohorts of HIV-infected persons only $[18,56,59,68-70]$. In addition, some conflicting data (in studies with small sample sizes) suggest that in contrast to women in the general population, age at menopause among $\mathrm{HIV}$-infected women may not be associated with current smoking [16], ethnicity [16], or fewer years of education [18, 54]. Additionally, although women with more advanced HIV infection and potentially lower BMI or wasting may be more likely to have amenorrhea, the association between BMI and the onset of menopause is inconsistent $[56,71]$ or absent [59] in the limited number of studies of HIV-infected women that have examined this association.

Also, more consistency regarding the definition of menopause, including FSH biological measurements, is warranted for future studies, because not all amenorrhea is menopause. Menopause is usually defined as the cessation of menses (amenorrhea) in women for $\geq 12$ consecutive months with symptoms suggestive of menopause and in which other causes of amenorrhea have been ruled out and/or the FSH level is elevated. Amenorrhea, which is defined as missing menstrual periods for at least three consecutive months [63], has been reported commonly among HIV-infected women and has been attributed to wasting [72] or anovulation [73]. Cejtin et al. reported that HIV infection was significantly associated with prolonged amenorrhea from causes other than menopause (OR: 3.16, 95\% CI: $1.26-7.95, P=0.02$ ) when adjusted for age [54]. Cejtin et al. reported that only $74.6 \%$ of $\mathrm{HIV}$-infected women who were age 45 years or older and had prolonged amenorrhea were truly menopausal [54], while nearly $90 \%$ of $\mathrm{HIV}$-uninfected women agedd $\geq 45$ years with 


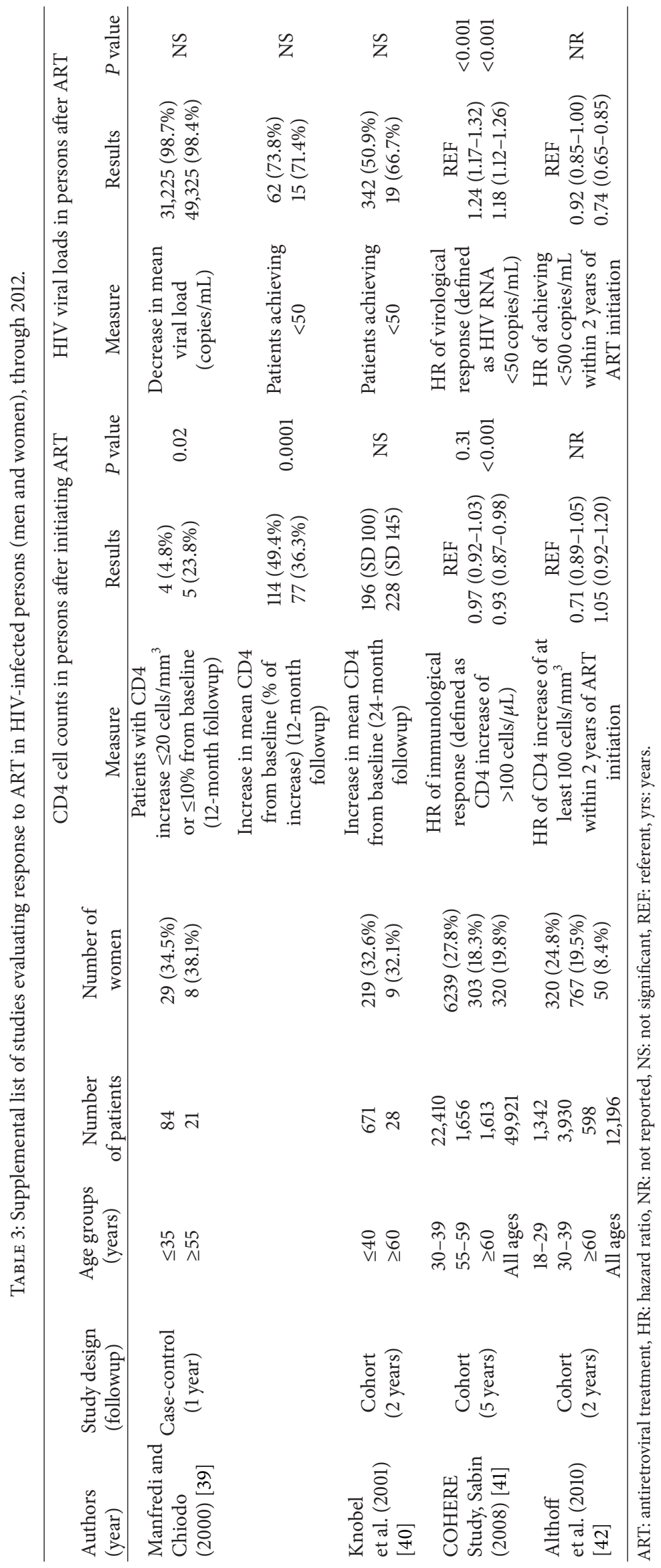


prolonged amenorrhea were truly menopausal [74]. Presence of menses may also be affected by use of ART; ART was significantly associated with having higher serum FSH among $\mathrm{HIV}$-infected women compared with uninfected women $(P<$ 0.05) [16]. Use of ART (HR: 0.48, 95\% CI: 0.32-0.71, $P=$ $0.003)$ and higher CD4 cell counts $(P=0.007)$ have been linked to a lower incidence of amenorrhea [75]. HIV-infected women who have HIV-related hypothalamic amenorrhea, especially those taking ART, may experience a return of menses once CD4 cell counts increase [75].

Menopause results in decreased ovarian synthesis of estrogen; estrogen and progesterone can effect HIV replication in peripheral blood mononuclear cells [76]. In animals, estrogen deficiency reduces the percentage of $\mathrm{T}$ cells in bone marrow [77]. Among HIV-uninfected women, postmenopausal women have lower CD4 cell counts than premenopausal women [78]. Estrogen deficiency associated with menopause and normal reduction in thymic tissue that accompanies aging [79] could affect CD4 cell recovery and HIV replication. Thus, post-menopausal women may respond differently to ART compared with pre-menopausal women.

Regarding the effect of menopause on ART response, we were unable to compare the Patterson et al. study [36] to any other report, because no other studies were conducted with only HIV-infected women. Although it is difficult to disentangle the effect of aging on response to ART, we assessed data from the supplementary articles (both women and men) in order to compensate for the paucity of specific data (women only) of the effect of menopause on response to ART. Data from the supplementary articles were inconsistent. Some data suggest that younger persons experience better immunological and/or virological responses to $\operatorname{ART}[44,50,52]$. The COHERE study showed that immunological response to ART was similar in the patients aged 55-59 years but poorer in those aged $\geq 60$ years, compared with the patients who were younger than the average age at menopause [41]. This finding may imply that the effects of aging on CD 4 cell count recovery are multifactorial, resulting from both normal age-related immunosenescence and by the negative effects of estrogen deficiency that occurs with menopause $[80,81]$. If a low CD4 cell count increases risk of early menopause, then the effects of HIV infection and menopause would be compounded; earlier diagnosis of HIV and initiating ART treatment before CD 4 cells are $<200$ cells $/ \mathrm{mm}^{3}$ would be warranted for women approaching menopause.

\section{Conclusion/Recommendations for Next Steps}

Understanding the effects of HIV infection on age at menopause and on response to ART is important for ensuring the best possible care for the expanding cohort of women living with HIV who approach and live through menopause and are taking ART. This information may also help inform clinicians and researchers to assess whether ART for middleaged women with HIV infection should be modified across menopause. Advanced HIV infection is a known independent risk factor for early mortality as well as both cardiovascular disease and decreased bone mineral density. Earlier onset of menopause is also associated with increased mortality $[82,83]$ and both decreased bone mineral density [84] and cardiovascular disease [85].

Our review highlights research deficits in our understanding of the effects of HIV infection on age at menopause and opportunities for future work. Ideally, studies of menopause in HIV-infected women should include sufficient numbers of women, both HIV-infected and HIV-uninfected, who are representative of the racially and ethnically diverse women living with or at risk of HIV infection in the United States. Such studies should follow women across menopause and capture data on the growing number of factors recognized to be related to age of menopause, including race/ethnicity, tobacco smoking, drug use, level of education, BMI, use of ART, CD4 cell counts, and HIV viral loads. Furthermore, a combination of questionnaires and laboratory measurement of serum FSH levels will improve classification of menopause in women, especially HIV-infected women for whom amenorrhea is highly prevalent. Additional data may also be helpful for clinicians managing HIV-infected women with chronic medical conditions that also disproportionately affect older black/African American and Hispanic/Latina women of color, such as diabetes and hypertension [86, 87].

Today, over 30 years since HIV was first identified, the number of women living with HIV infection, taking ART, and living longer and healthier lives is expanding. Epidemiological studies of older, menopausal women living with HIV infection are needed to address questions raised as this epidemiologic landscape changes. Such studies will provide important data that will help to optimize care for the growing numbers of post-menopausal women living with HIV infection.

\section{Disclaimer}

The findings and conclusions in this report are those of the authors and do not necessarily represent the official position of the Centers for Disease Control and Prevention.

\section{Conflict of Interests}

The authors have no conflict of interests relevant to this paper.

\section{References}

[1] K. Porter, "Determinants of survival following HIV-1 seroconversion after the introduction of HAART," The Lancet, vol. 362, no. 9392, pp. 1267-1274, 2003.

[2] M. A. Hacker, M. L. Petersen, M. Enriquez, and F. I. Bastos, "Highly active antiretroviral therapy in Brazil: the challenge of universal access in a context of social inequality," Revista Panamericana de Salud Publica/Pan American Journal of Public Health, vol. 16, no. 2, pp. 78-83, 2004.

[3] K. P. High, M. Brennan-Ing, D. B. Clifford et al., "HIV and aging: state of knowledge and areas of critical need for research. 
A report to the NIH Office of AIDS Research by the HIV and Aging Working Group," Journal of Acquired Immune Deficiency Syndromes, vol. 60, supplement 1, pp. S1-18, 2012.

[4] J. T. Brooks, K. Buchacz, K. A. Gebo, and J. Mermin, "HIV infection and older americans: the public health perspective," The American Journal of Public Health, vol. 102, pp. 1516-1526, 2012.

[5] "UNAIDS report on the global AIDS epidemic 2010," http:// www.unaids.org/documents/20101123_globalreport_em.pdf.

[6] The Centers for Disease Control and Prevention, "Diagnoses of HIV infection in the United States and dependent areas," HIV Surveillance Report 23, 2011, http://www.cdc.gov/hiv/surveillance/resources/reports/2011report/index.htm.

[7] The Centers for Disease Control and Prevention, "HIV among Women," 2011, http://www.cdc.gov/hiv/topics/women/pdf/ women.pdf.

[8] L. Linley, J. Prejean, Q. An, M. Chen, and H. I. Hall, "Racial/ethnic disparities in HIV diagnoses among persons aged 50 years and older in 37 states, 2005-2008," The American Journal of Public Health, vol. 102, pp. 1527-1534, 2012.

[9] Kaiser Family Foundation, "A report on women and HIV/AIDS in the U.S.", http://kaiserfamilyfoundation.files.wordpress.com/ 2013/04/8436.pdf.

[10] M. D. Fan, B.-S. Maslow, N. Santoro, and E. Schoenbaum, "HIV and the menopause," Menopause International, vol. 14, no. 4, pp. 163-168, 2008.

[11] D. Grady and G. F. Sawaya, "Discontinuation of postmenopausal hormone therapy," The American Journal of Medicine, vol. 118, supplement 12, pp. 163-165, 2005.

[12] C. N. Soares, "Practical strategies for diagnosing and treating depression in women: menopausal transition," The Journal of Clinical Psychiatry, vol. 69, no. 10, article e30, 2008.

[13] M. Sowers, H. Zheng, K. Tomey et al., "Changes in body composition in women over six years at midlife: ovarian and chronological aging," Journal of Clinical Endocrinology and Metabolism, vol. 92, no. 3, pp. 895-901, 2007.

[14] V. R. Mesch, N. O. Siseles, P. N. Maidana et al., "Androgens in relationship to cardiovascular risk factors in the menopausal transition," Climacteric, vol. 11, no. 6, pp. 509-517, 2008.

[15] N. Santoro, M. Fan, B. Maslow, and E. Schoenbaum, "Women and HIV infection: the makings of a midlife crisis," Maturitas, vol. 64, no. 3, pp. 160-164, 2009.

[16] E. E. Schoembaum, D. Hartel, Y. Lo et al., "HIV infection, drug use, and onset of natural menopause," Clinical Infectious Diseases, vol. 41, no. 10, pp. 1517-1524, 2005.

[17] L. E. Fantry, M. Zhan, G. H. Taylor, A. M. Sill, and J. A. Flaws, "Age of menopause and menopausal symptoms in HIV-infected women," AIDS Patient Care and STDS, vol. 19, no. 11, pp. 703711, 2005.

[18] M. de Pommerol, M. Hessamfar, S. Lawson-Ayayi et al., "Menopause and HIV infection: age at onset and associated factors, ANRS CO3 Aquitaine cohort," International Journal of STD and AIDS, vol. 22, no. 2, pp. 67-72, 2011.

[19] L. C. Kahwati, L. Haigler, and S. Rideout, "What is the best way to diagnose menopause?" Journal of Family Practice, vol. 54, no. 11, pp. 1000-1002, 2005.

[20] B. Julg, D. Poole, M. Ghebremichael et al., "Factors predicting discordant virological and immunological responses to antiretroviral therapy in HIV-1 clade C infected zulu/xhosa in South Africa," PLoS ONE, vol. 7, no. 2, Article ID e31161, 2012.

[21] G. R. Kaufmann, H. Furrer, B. Ledergerber et al., "Characteristics, determinants, and clinical relevance of $\mathrm{CD} 4 \mathrm{~T}$ cell recovery to $<500$ cells $/ \mu \mathrm{L}$ in HIV type 1-infected individuals receiving potent antiretroviral therapy," Clinical Infectious Diseases, vol. 41, no. 3, pp. 361-372, 2005.

[22] A. L. Moore, A. Mocroft, S. Madge et al., "Gender differences in virologic response to treatment in an HIV-positive population: a cohort study," Journal of Acquired Immune Deficiency Syndromes, vol. 26, no. 2, pp. 159-163, 2001.

[23] N. Khanna, M. Opravil, H. Furrer et al., "CD4+ T cell count recovery in HIV type 1-infected patients is independent of class of antiretroviral therapy," Clinical Infectious Diseases, vol. 47, pp. 1093-1101, 2008.

[24] K. B. Patterson, S. Napravnik, J. Eron, J. Keruly, and R. Moore, "Effects of age and sex on immunological and virological responses to initial highly active antiretroviral therapy," $H I V$ Medicine, vol. 8, no. 6, pp. 406-410, 2007.

[25] C. E. Ferreira, A. M. Pinto-Neto, D. M. Conde, L. CostaPaiva, S. S. Morais, and J. Magalhães, "Menopause symptoms in women infected with HIV: prevalence and associated factors," Gynecological Endocrinology, vol. 23, no. 4, pp. 198-205, 2007.

[26] R. A. Clark, S. E. Cohn, C. Jarek et al., "Perimenopausal symptomatology among HIV-infected women at least 40 years of age," Journal of Acquired Immune Deficiency Syndromes and Human Retrovirology, vol. 23, no. 1, pp. 99-100, 2000.

[27] R. Kohli, R. S. Klein, E. E. Schoenbaum, K. Anastos, H. Minkoff, and H. S. Sacks, "Aging and HIV infection," Journal of Urban Health, vol. 83, no. 1, pp. 31-42, 2006.

[28] E. M. Kojic, C.-C. Wang, and S. Cu-Uvin, "HIV and menopause: a review," Journal of Women's Health, vol. 16, no. 10, pp. 14021411, 2007.

[29] A. Monroe, "Menstruation, menopause, and HIV," Bulletin of Experimental Treatments for AIDS, vol. 19, no. 2, pp. 39-44, 2007.

[30] H. E. Cejtin, "Care of the human immunodeficiency virusinfected menopausal woman," The American Journal of Obstetrics and Gynecology, vol. 207, pp. 87-93, 2012.

[31] D. M. Conde, A. M. Pinto-Neto, and L. Costa-Paiva, "Age at menopause of HIV-infected women: a review," Gynecological Endocrinology, vol. 24, no. 2, pp. 84-86, 2008.

[32] H. E. Cejtin, "Gynecologic Issues in the HIV-Infected Woman," Infectious Disease Clinics of North America, vol. 22, no. 4, pp. 709-739, 2008.

[33] D. M. Conde, E. T. Silva, W. N. Amaral et al., "HIV, reproductive aging, and health implications in women: a literature review," Menopause, vol. 16, no. 1, pp. 199-213, 2009.

[34] E. M. Kojic and S. Cu-Uvin, "Special care issues of women living with HIV-AIDS," Infectious Disease Clinics of North America, vol. 21, no. 1, pp. 133-148, 2007.

[35] S. H. K. Cejtin, R. Taylor, and D. H. Watts, "Assessment of menopausal status among women in the Women's Interagency HIV Study, (WIHS)," in Proceedings of the 57 International AIDS Conference, Bangkok, Thailand, 2004.

[36] K. B. Patterson, S. E. Cohn, J. Uyanik, M. Hughes, M. Smurzynski, and J. J. Eron, "Treatment responses in antiretroviral treatment-naive premenopausal and postmenopausal HIV-1infected women: an analysis from AIDS clinical trials group studies," Clinical Infectious Diseases, vol. 49, no. 3, pp. 473-476, 2009.

[37] K. A. Gebo, "HIV and aging: implications for patient management," Drugs and Aging, vol. 23, no. 11, pp. 897-913, 2006.

[38] K. A. Gebo, "Epidemiology of HIV and response to antiretroviral therapy in the middle aged and elderly," Aging Health, vol. 4, no. 6, pp. 615-627, 2008. 
[39] R. Manfredi and F. Chiodo, "A case-control study of virological and immunological effects of highly active antiretroviral therapy in HIV-infected patients with advanced age," AIDS, vol. 14, no. 10, pp. 1475-1477, 2000.

[40] H. Knobel, A. Guelar, G. Valldecillo et al., "Response to highly active antiretroviral therapy in HIV-infected patients aged 60 years or older after 24 months follow-up," AIDS, vol. 15, no. 12, pp. 1591-1593, 2001.

[41] C. Sabin, "Response to combination antiretroviral therapy: variation by age," AIDS, vol. 22, no. 12, pp. 1463-1473, 2008.

[42] K. N. Althoff, A. C. Justice, S. J. Gange et al., "Virologic and immunologic response to HAART, by age and regimen class," AIDS, vol. 24, no. 16, pp. 2469-2479, 2010.

[43] C. A. Sabin, C. J. Smith, V. Delpech et al., "The associations between age and the development of laboratory abnormalities and treatment discontinuation for reasons other than virological failure in the first year of highly active antiretroviral therapy," HIV Medicine, vol. 10, no. 1, pp. 35-43, 2009.

[44] J.-P. Viard, A. Mocroft, A. Chiesi et al., "Influence of age on CD4 cell recovery in human immunodeficiency virus-infected patients receiving highly active antiretroviral therapy: evidence from the EuroSIDA study," Journal of Infectious Diseases, vol. 183, no. 8, pp. 1290-1294, 2001.

[45] T. E. Yamashita, J. P. Phair, A. Muñoz et al., "Immunologic and virologic response to highly active antiretroviral therapy in the Multicenter AIDS Cohort Study," AIDS, vol. 15, no. 6, pp. 735746, 2001.

[46] R. Manfredi, L. Calza, D. Cocchi, and F. Chiodo, "Antiretroviral treatment and advanced age: epidemiologic, laboratory, and clinical features in the elderly," Journal of Acquired Immune Deficiency Syndromes, vol. 33, no. 1, pp. 112-114, 2003.

[47] J. L. Perez and R. D. Moore, "Greater effect of highly active antiretroviral therapy on survival in people aged $\geq 50$ years compared with younger people in an urban observational cohort," Clinical Infectious Diseases, vol. 36, no. 2, pp. 212-218, 2003.

[48] M. Tumbarello, R. Rabagliati, K. De Gaetano Donati et al., "Older HIV-positive patients in the era of highly active antiretroviral therapy: changing of a scenario," AIDS, vol. 17, no. 1, pp. 128-131, 2003.

[49] K. Goodkin, P. Shapshak, D. Asthana et al., "Older age and plasma viral load in HIV-1 infection," AIDS, vol. 18, supplement 1, pp. S87-S98, 2004.

[50] S. Grabar, I. Kousignian, A. Sobel et al., "Immunologic and clinical responses to highly active antiretroviral therapy over 50 years of age. Results from the French Hospital Database on HIV," AIDS, vol. 18, no. 15, pp. 2029-2038, 2004.

[51] M. Tumbarello, R. Rabagliati, K. de Gaetano Donati et al., "Older age does not influence CD4 cell recovery in HIV-1 infected patients receiving Highly Active Anti Retroviral Therapy," BMC Infectious Diseases, vol. 4, article 46, 2004.

[52] L. Cuzin, C. Delpierre, S. Gerard, P. Massip, and B. Marchou, "Immunologic and clinical responses to highly active antiretroviral therapy in patients with HIV infection aged $>50$ years," Clinical Infectious Diseases, vol. 45, no. 5, pp. 654-657, 2007.

[53] M. J. Silverberg, W. Leyden, M. A. Horberg, G. N. DeLorenze, D. Klein, and C. P. Quesenberry Jr., "Older age and the response to and tolerability of antiretroviral therapy," Archives of Internal Medicine, vol. 167, no. 7, pp. 684-691, 2007.

[54] H. E. Cejtin, A. Kalinowski, P. Bacchetti et al., "Effects of human immunodeficiency virus on protracted amenorrhea and ovarian dysfunction," Obstetrics and Gynecology, vol. 108, no. 6, pp. 1423-1431, 2006.
[55] S. E. Barkan, S. L. Melnick, S. Preston-Martin et al., "The women's Interagency HIV study," Epidemiology, vol. 9, no. 2, pp. 117-125, 1998.

[56] J. T. Bromberger, K. A. Matthews, L. H. Kuller, R. R. Wing, E. N. Meilahn, and P. Plantinga, "Prospective study of the determinants of age at menopause," The American Journal of Epidemiology, vol. 145, no. 2, pp. 124-133, 1997.

[57] E. B. Gold, J. Bromberger, S. Crawford et al., "Factors associated with age at natural menopause in a multiethnic sample of midlife women," The American Journal of Epidemiology, vol. 153, no. 9, pp. 865-874, 2001.

[58] M. Kaczmarek, "The timing of natural menopause in Poland and associated factors," Maturitas, vol. 57, no. 2, pp. 139-153, 2007.

[59] F. Parazzini, "Determinants of age at menopause in women attending menopause clinics in Italy," Maturitas, vol. 56, no. 3, pp. 280-287, 2007.

[60] D. de Aloysio, P. di Donato, N. A. Giulini et al., "Premature ovarian failure: frequency and risk factors among women attending a network of menopause clinics in Italy," BJOG, vol. 110, no. 1, pp. 59-63, 2003.

[61] J. L. Luborsky, P. Meyer, M. F. Sowers, E. B. Gold, and N. Santoro, "Premature menopause in a multi-ethnic population study of the menopause transition," Human Reproduction, vol. 18, no. 1, pp. 199-206, 2003.

[62] R. A. Clark, K. Mulligan, E. Stamenovic et al., "Frequency of anovulation and early menopause among women enrolled in selected Adult AIDS Clinical Trials Group Studies," Journal of Infectious Diseases, vol. 184, no. 10, pp. 1325-1327, 2001.

[63] The Centers for Disease Control and Prevention, "Women's Reproductive Health: Menopause," http://www.cdc.gov/reproductivehealth/WomensRH/Menopause.htm.

[64] N. Santoro, Y. Lo, G. Moskaleva et al., "Factors affecting reproductive hormones in HIV-infected, substance-using middleaged women," Menopause, vol. 14, no. 5, pp. 859-865, 2007.

[65] Z. Dou, J. Xu, J. H. Jiao et al., "Gender difference in 2-year mortality and immunological response to ART in an HIVinfected Chinese population, 2006-2008," PLoS ONE, vol. 6, no. 8, Article ID e22707, 2011.

[66] D. Maman, M. Pujades-Rodriguez, F. Subtil et al., "Gender differences in immune reconstitution: a multicentric cohort analysis in sub-saharan africa," PLoS ONE, vol. 7, no. 2, Article ID e31078, 2012.

[67] K. M. van Asselt, H. S. Kok, Y. T. van der Schouw et al., “Current smoking at menopause rather than duration determines the onset of natural menopause," Epidemiology, vol. 15, no. 5, pp. 634-639, 2004.

[68] R. A. Clark and R. Bessinger, "Clinical manifestations and predictors of survival in older women infected with HIV," Journal of Acquired Immune Deficiency Syndromes and Human Retrovirology, vol. 15, no. 5, pp. 341-345, 1997.

[69] D. J. Torgerson, A. Avenell, I. T. Russell, and D. M. Reid, "Factors associated with onset of menopause in women aged 45-49," Maturitas, vol. 19, no. 2, pp. 83-92, 1994.

[70] S. A. Miller, N. Santoro, Y. Lo et al., "Menopause symptoms in HIV-infected and drug-using women," Menopause, vol. 12, no. 3, pp. 348-356, 2005.

[71] W. Willett, M. J. Stampfer, and C. Bain, "Cigarette smoking, relative weight, and menopause," The American Journal of Epidemiology, vol. 117, no. 6, pp. 651-658, 1983. 
[72] S. Grinspoon, C. Corcoran, K. Miller et al., "Body composition and endocrine function in women with acquired immunodeficiency syndrome wasting," Journal of Clinical Endocrinology and Metabolism, vol. 82, pp. 1332-1337, 1997.

[73] R. M. Greenblatt, N. Ameli, R. M. Grant, P. Bacchetti, and R. N. Taylor, "Impact of the ovulatory cycle on virologic and immunologic markers in HIV-infected women," Journal of Infectious Diseases, vol. 181, no. 1, pp. 82-90, 2000.

[74] R. B. Wallace, B. M. Sherman, and J. A. Bean, "Probability of menopause with increasing duration of amenorrhea in middleaged women," The American Journal of Obstetrics and Gynecology, vol. 135, no. 8, pp. 1021-1024, 1979.

[75] L. S. Massad, C. T. Evans, H. Minkoff et al., "Effects of HIV infection and its treatment on self-reported menstrual abnormalities in women," Journal of Women's Health, vol. 15, no. 5, pp. 591-598, 2006.

[76] S. N. Asin, A. M. Heimberg, S. K. Eszterhas, C. Rollenhagen, and A. L. Howell, "Estradiol and progesterone regulate HIV type 1 replication in peripheral blood cells," AIDS Research and Human Retroviruses, vol. 24, no. 5, pp. 701-716, 2008.

[77] F. F. Safadi, I. R. Dissanayake, G. G. Goodman et al., "Influence of estrogen deficiency and replacement on T-cell populations in rat lymphoid tissues and organs," Endocrine, vol. 12, no. 1, pp. 81-88, 2000.

[78] T. Giglio, M. A. Imro, G. Filaci et al., "Immune cell circulating subsets are affected by gonadal function," Life Sciences, vol. 54, no. 18, pp. 1305-1312, 1994.

[79] R. C. Kalayjian, A. Landay, R. B. Pollard et al., "Age-related immune dysfunction in health and in human immunodeficiency virus (HIV) disease: association of age and HIV infection with naive CD8+ cell depletion, reduced expression of CD28 on CD8+ cells, and reduced thymic volumes," Journal of Infectious Diseases, vol. 187, no. 12, pp. 1924-1933, 2003.

[80] B. H. B. van Benthem, P. Vernazza, R. A. Coutinho, and M. Prins, "Impact of pregnancy and menopause on CD4 cell counts," Journal of Acquired Immune Deficiency Syndromes, vol. 38, no. 1, p. S22, 2005.

[81] M. Rodriguez-Garcia, N. Biswas, M. V. Patel et al., "Estradiol reduces susceptibility of $\mathrm{CD} 4(+) \mathrm{T}$ cells and macrophages to HIV-infection," PLoS ONE, vol. 8, no. 4, Article ID e62069, 2013.

[82] G. S. Cooper and D. P. Sandler, "Age at natural menopause and mortality, Annals of Epidemiology, vol. 8, no. 4, pp. 229-235, 1998.

[83] B. K. Jacobsen, I. Heuch, and G. Kvåle, "Age at natural menopause and all-cause mortality: a 37-year follow-up of 19,731 Norwegian women," The American Journal of Epidemiology, vol. 157, no. 10, pp. 923-929, 2003.

[84] J. A. Cauley, M. E. Danielson, G. A. Greendale et al., "Bone resorption and fracture across the menopausal transition: the Study of Women's Health Across the Nation," Menopause, vol. 19, no. 11, pp. 1200-1207, 2012.

[85] M. Wellons, P. Ouyang, P. J. Schreiner, D. M. Herrington, and D. Vaidya, "Early menopause predicts future coronary heart disease and stroke: the multi-ethnic study of atherosclerosis," Menopause, vol. 19, no. 10, pp. 1081-1087, 2012.

[86] N. Redmond, H. J. Baer, and L. S. Hicks, "Health behaviors and racial disparity in blood pressure control in the national health and nutrition examination survey," Hypertension, vol. 57, no. 3 , pp. 383-389, 2011.

[87] C. L. Link and J. B. McKinlay, "Disparities in the prevalence of diabetes: is it race/ethnicity or socioeconomic status? Results from the Boston Area Community Health (BACH) survey," Ethnicity and Disease, vol. 19, no. 3, pp. 288-292, 2009. 


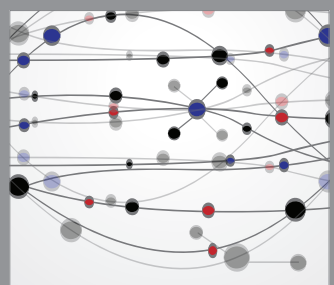

The Scientific World Journal
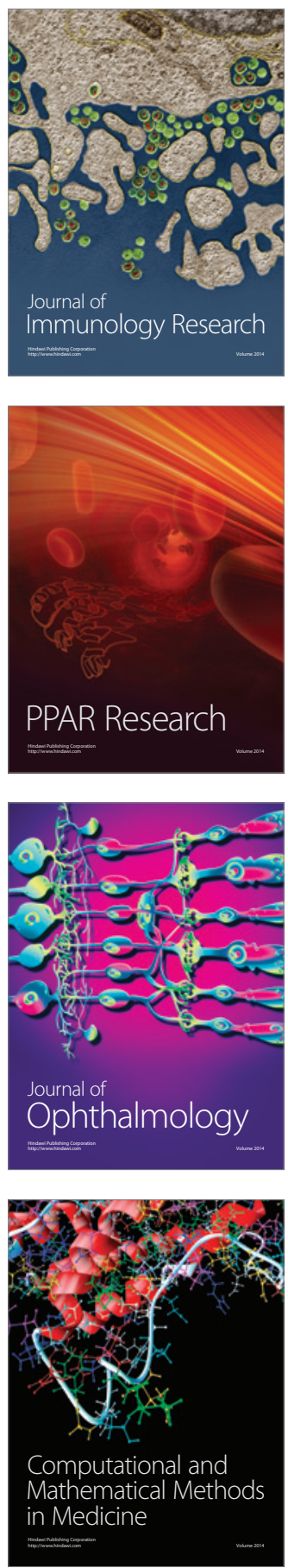

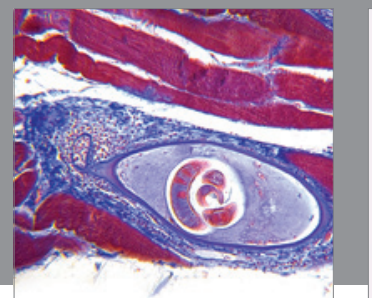

Gastroenterology

Research and Practice
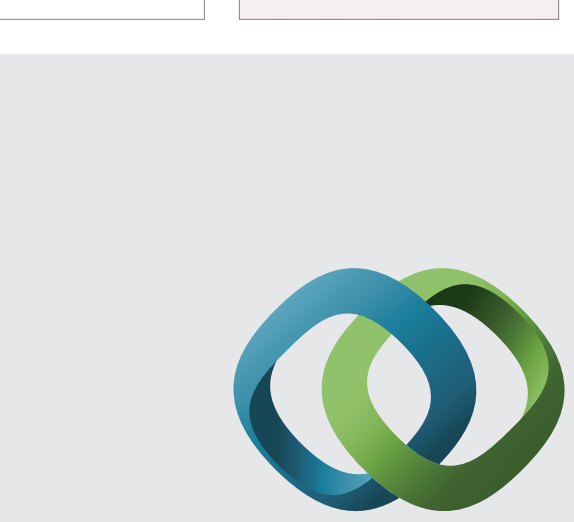

\section{Hindawi}

Submit your manuscripts at

http://www.hindawi.com
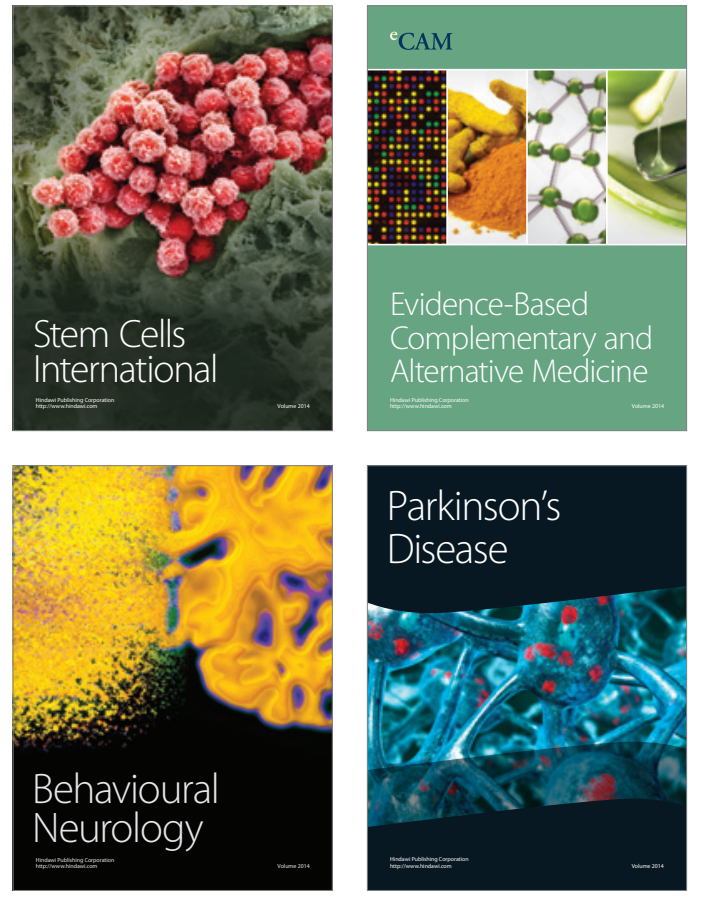
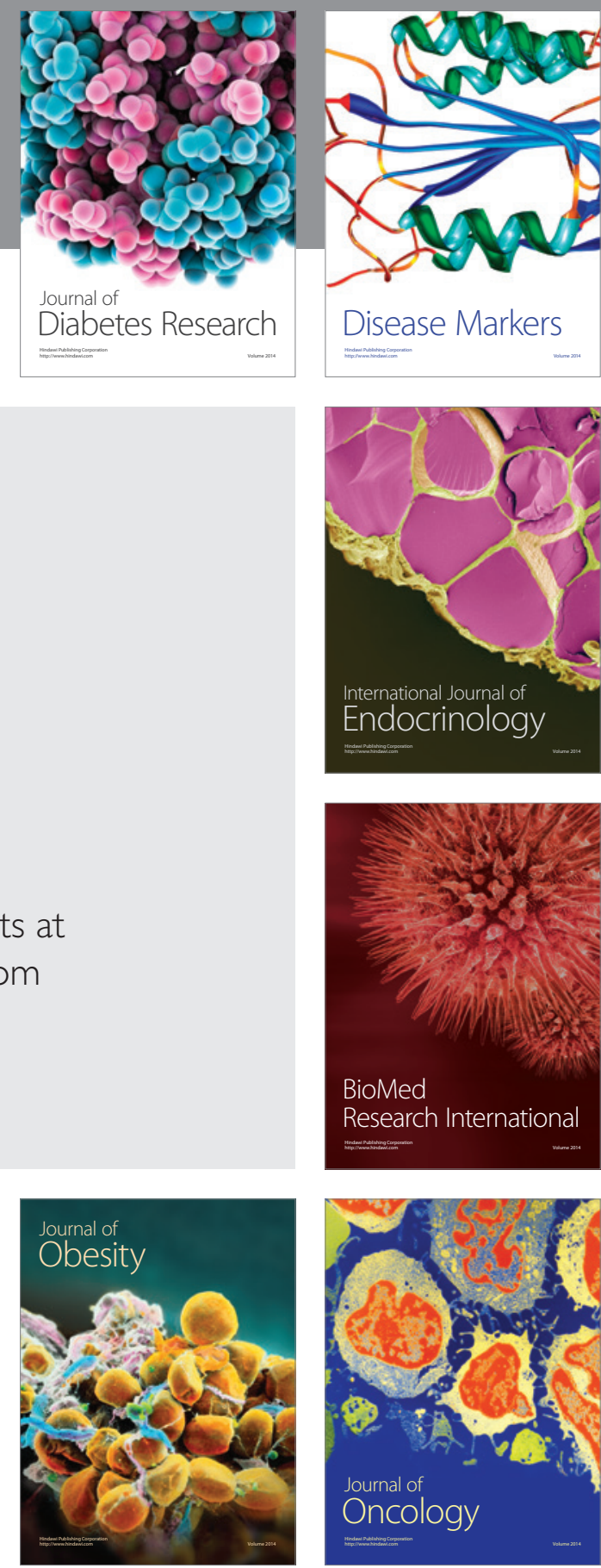

Disease Markers
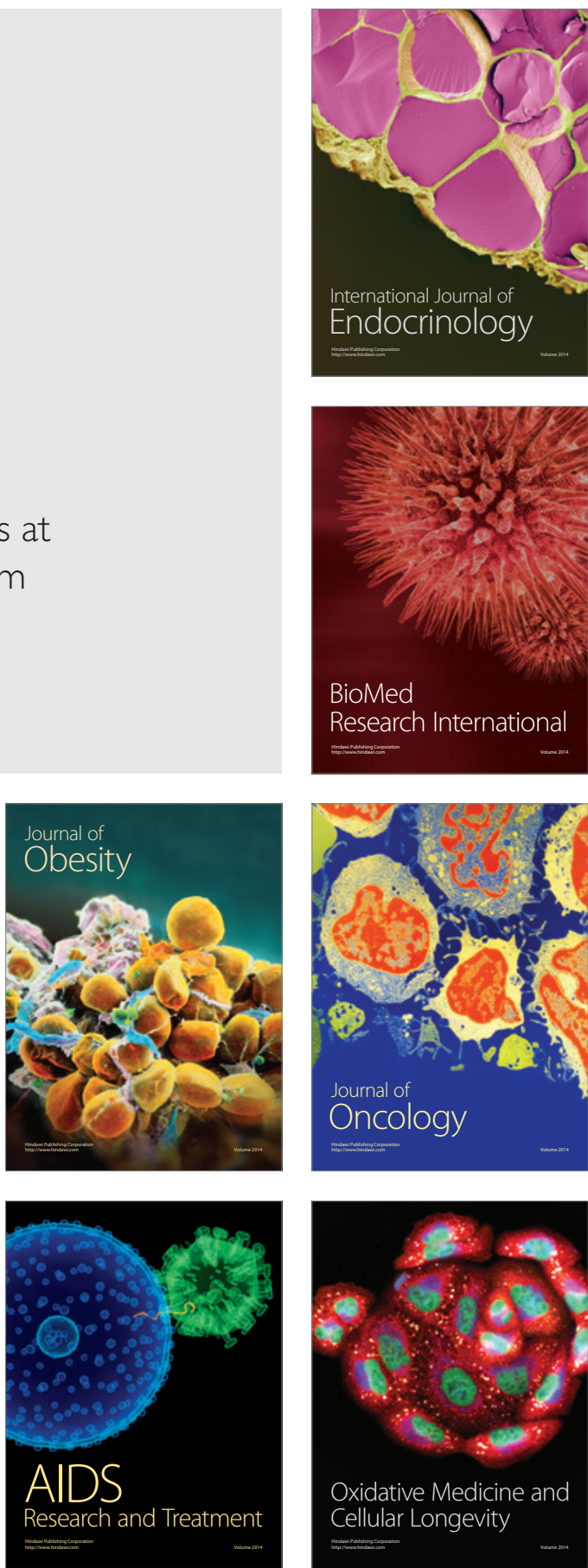